\title{
Szorongás, depresszió és egészségkontrollhit kapcsolata a metabolikus szindrómával
}

\author{
Rafael Beatrix ${ }^{1,2,3}$, Péter Lea ${ }^{3}$, Kósa István \\ 'SZTE ÁOK, Preventív Medicina Tanszék, Szeged \\ 'SZTE BTK, Pszichológiai Intézet, Szeged \\ 3'Szent-Györgyi Albert Klinikai Központ, Ápolásvezetési és Szakdolgozói Oktatási Igazgatás, Szeged \\ Levelezési cím: \\ Dr. Rafael Beatrix, e-mail: rafaelbeatrix@gmail.com
}

\begin{abstract}
A publikáció célja elemezni a depresszió, a szorongás és az egészségkontrollhit kapcsolatát a metabolikus szindrómával. A metabolikus szindrómában (MS) szenvedők száma évről évre nő. Mivel ismert rizikótényezője a szív- és érrendszeri megbetegedéseknek és a 2-es típusú diabétesznek, ezért fontos azon tényezők feltárása, amelyek változtatásával e szindróma megelőzhető, vagy az ebben szenvedők életszínvonala javitható.

Eddigi kutatások szerint elhízás esetén (BMI >30) kb. 20-45\%-kal gyakrabban van jelen unipoláris depresszió, pánikbetegség, illetve bipoláris zavar és szignifikáns összefüggést találtak férfiak esetében a depressziós tünetek és a zsigeri elhízás között, míg nőknél a depresszió és a hyperglykaemia között. A metabolikus szindróma unipoláris depresszióban $40-48 \%$-ban, míg bipoláris zavarnál 25 és $49 \%$ között van jelen.

Az egészséggel kapcsolatos kontrollhit befolyásolja az egyén egészséggel kapcsolatos viselkedését, és ez által meghatározza az egészségi állapotát. A belső kontrollhit pozitív egészségmagatartásokkal, pozitív érzelmekkel, míg a külső kontrollhit két csoportja (társas külső kontrollhit és véletlen külső kontrollhit) egészségtelenebb viselkedésmódokkal (dohányzás, alkoholfogyasztás, egészségtelenebb étkezés, kevesebb testmozgás) áll összefüggésben, amelyek növelhetik a metabolikus szindróma kialakulásának esélyét.

A metabolikus szindróma elsődlegesen életmódváltással kezelhető kórkép. A tartós testsúlycsökkenés és életmódváltás egy hosszú, komplex folyamatot igényel, amelyben a pszichoszociális tényezők is kiemelkedő szerepet játszanak.

Kulcsszavak: metabolikus szindróma, depresszió, szorongás, egészségkontrollhit, egészségmagatartás
\end{abstract}

\section{The role of anxiety, depression and health locus of control in metabolic syndrome}

The publication aims to analyse the connection between depression, anxiety, and health locus of control with metabolic snydrome.

The number of patients suffering from metabolic syndrome (MS) is growing continually. The exploration of those wellknown risk factors of cardiovascular diseases and type 2 diabetes is important as with the modification of these factors we can prevent this syndrome and the quality of life can be improved.

According to the investigations occupying with obesity $(\mathrm{BMI}>30)$ unipolar depressive disorders, panic disorder, and bipolar disorders are present $20-45 \%$ more than in the population living with normal weight. A significant connection is found between depressive disorders and visceral obesity in men, while the connection between depression and hypoglycemia is representative in women. The metabolic syndrome is present in the case of unipolar depression $40-48 \%$ while the rate of presence in bipolar disorders is between $25-49 \%$.

The internal health locus of control influences health behavior determining health surveillance this way. The internal health locus of control is closely related to positive health behavior and feelings while the two groups of while the two groups of external health locus of control (powerful other locus and chance locus) are connected with more unhealthy ways of behavior (smoking, alcohol, unhealthy food, fewer exercises) which can increase the development of metabolic syndrome. The treatment of metabolic syndrome is particularly the change of lifestyle. The permanent weight-loss and the change of lifestyle are parts of a long and complex process where the psychosocial factors also have significant roles.

Keywords: metabolic syndrome, depression, anxiety, locus of health control, health behavior

A kézirat 2020. 09. 01-én érkezett a szerkesztőségbe, 2020. 10. 21-én került elfogadásra. 


\section{Bevezetés}

Közismert, hogy az egészségügyi ellátások súlypontja a XXI. századra átstrukturálódott, fókusza az infekciók, sérülések ellátása felöl a hosszú távú ellátást igénylő, úgynevezett civilizációs betegségekre - mint a cukorbetegség, magas vérnyomás, elhízás - és az onkológiai betegségekre helyeződött át. Az ilyen hosszú lefolyású betegségek ellátása köti le az egészségügyi költségvetés meghatározó részét a fejlett társadalmakban, arányuk amerikai adatok szerint eléri a teljes egészséggazdasági költségvetés $75 \%$-át (1). Bár a civilizációs betegségek kialakulásában, illetve lefolyásában meghatározó szerepet játszik a betegek életmódja, a modern, „nyugati típusú” orvoslásban ezen tényezök kezelése háttérben marad, az előtérben a gyógyszeres terápiák és eszközös beavatkozások alkalmazása áll (2).

Publikációnkban a metabolikus szindróma meghatározása és jellemzőinek bemutatását követően a szindróma kapcsolatát elemezzük a depresszióval a szorongással és az egészségkontollhittel, ezáltal rámutatva arra, hogy e tünetegyüttes menedzselése egy hoszszú, komplex folyamatot igényel. E folyamatban a pszichoszociális tényezők kiemelkedő szerepet játszanak, így a tünetegyüttes orvoslásában kiemelten fontos $-a z$ orvostudományban a biomedikális modell helyett egyre inkább elterjedt - biopszichoszociális modellre épülő komplex betegvizsgálat.

A biopszichoszociális orvoslás fogalma George Engel amerikai pszichiáter nevéhez füződik, aki 1977-ben alkotta meg téziseit, szembe menve az akkor uralkodó biomedikális nézetekkel, azaz a természettudományos meghatározottságot a lelki jelenségek vizsgálatával, valamint társadalmi szempontok bevonásával egészítette ki, létrehozva egy holisztikus szemléletet, amely betegségközpontú és nem betegközpontú. A biopszichoszociális elképzelés hangsúlyozza, hogy a betegségek kialakulásában nem csupán a biológiai tényezők, hanem a pszichológiai és a társadalmi összetevők is igen fontosak. Általános rendszerelmélet adja az alapját, amelyben a cirkuláris okság váltja fel a lineáris kauzalitás modelljét, amely a hagyományos biomedicinális megközelítés csapdáját jelenti. A betegségek biopszichoszociális modellje szerint kialakulásukban többféle tényezőnek van szerepe, és ebböl következik, hogy a terápiában is érdemes integrációra törekedni (3).

\section{A metabolikus szindróma meghatározása és jellemzői}

A civilizációs betegségek egyike a metabolikus szindróma (MS) napjaink egyik leggyakoribb tünetegyüttese, amely az európai országok férfi lakosságának $41 \%$-át, míg a nök $38 \%$-át érinti, közülük is nagyobb számban a 65 év felettieket. Az érintettek száma évröl évre növekszik (4).
A szindróma definíciójáról, diagnosztikai kritériumairól eltérő álláspontok születtek és máig nem született teljesen egységes megállapodás arra vonatkozóan, hogy önálló diagnózisként megállja-e a helyét, vagy csak betegségmegelőző állapotként értelmezendő. A Magyar Diabetes Társaság (MDT) a nemzetközi társaságok ajánlásai alapján a következőképpen definiálja: genetikai prediszpozíció, helytelen életmód és táplálkozás hatására jelentkező anyagcserezavar, mely 2-es típusú diabéteszhez és kardiovaszkuláris betegségek okozta korai elhalálozáshoz vezethet (5). A metabolikus szindróma kialakulása inzulinrezisztenciára vezethető viszsza, ennek következtében kialakuló tünetei a magas vérinzulin-tartalom (hyperinsulinaemia), magas vércukor- és koleszterinszint, magas vérnyomás (hipertónia), zsigeri hasi elhízás (visceralis obesitas) és zsíranyagcsere-zavar (dyslipidaemia) (6).

2011-ben az V. Magyar Kardiovaszkuláris Konszenzus Konferencia a magyar populációra nézve a következő kritériumokat határozta meg:

1. A haskörfogat férfiaknál $102 \mathrm{~cm}$ felett, nőknél $88 \mathrm{~cm}$ felett kóros.

2. A trigliceridszint $1,7 \mathrm{mmol} / /$ érték felett kóros (vagy emiatt folytatott gyógyszeres kezelés).

3. A HDL-koleszterin-szint férfiaknál $1,0 \mathrm{mmol} / \mathrm{l}$ alatt, nőknél 1,3 mmol/l alatt kóros, (vagy emiatt folytatott gyógyszeres kezelés).

4. Az éhgyomri vércukor $5,6 \mathrm{mmol} / \mathrm{l}$ feletti vagy 2 -es típusú cukorbetegség igazolt.

5. A vérnyomás $130 / 85 \mathrm{Hgmm}$ felett kóros. Amennyiben a felsorolt öt kritérium közül három jelen van, akkor a metabolikus szindróma igazolt (7).

Nádas 2009-ben a nemzetközi kritériumrendszer alapján 1-es típusú cukorbetegekkel végzett magyar kutatásában 533 felnőttből 193-nál (36,2\%) mutatta ki a metabolikus szindróma meglétét. A nemek között nem mutatkozott szignifikáns különbség (8). Ez egybeesik a 2010-ben indult a „Magyarország Átfogó Egészségvédelmi Szűrőprogramja 2010-2020" (MÁESZ) program első éveinek eredményével. A program célja a népegészségügyi szempontból veszélyes betegségek (szív- és érrendszeri, tüdőbetegség, cukorbetegség stb.) korai felismerése és az anyagcserezavarok felderítése volt 1500 helyszínen, összesen nyolcmillió vizsgálat elvégzésével. Kékes és munkatársai a szürőprogram első három évének eredményeit publikálta: 65267 felnőtt személynél 1597163 vizsgálatot végeztek, a résztvevők $57 \%$-a nő és $43 \%$-a férfi volt. Az életkori megoszlásban 13\% 18-25 év közötti, 50\% 26-55 év közötti, $19 \% 56-65$ év közötti és $11 \% 65$ évesnél idősebb volt. A metabolikus szindróma diagnózisához három tényezőt vettek figyelembe: haskörfogat, vércukor, vérnyomás. Ez alapján a vizsgált populáció 33-38\%-ában fordult elő, 45 éves korig férfiaknál szignifikánsan gyakrabban, 46 és 65 év között pedig a nők körében (9).

Simmons és munkatársai rámutattak arra, hogy bár a metabolikus szindróma gyakorisága és a témában szü- 
letett vizsgálatok száma nő, egységes patopszichológiai mechanizmust egyik sem tudott kimutatni, illetve a legtöbb kritériumrendszer egyáltalán nem tér ki az életkorra, a dohányzás, vagy a fizikai aktivitás szerepére, de az említett kockázati tényezők kombinációinak prediktív értéke sem tisztázott. Ezért arra a következtetésre jutottak, hogy a metabolikus szindróma, mint klinikai diagnózis önmagában nem helytálló, sokkal inkább a 2-es típusú cukorbetegséget és a kardiovaszkuláris betegségeket megelőző állapotként tekinthető és edukációs jelentőséggel bír (10).

\section{A szorongás és depresszió kapcsolata a metabolikus szindrómával}

A depresszió - a metabolikus szindrómához hasonlóan - szintén népbetegségnek számít. Nemzetközi és hazai adatok szerint a felnőtt lakosság csaknem $20 \%$-át érinti élete során legalább egyszer, 10\%-át pedig élete során többször, vagy krónikusan, ami 322 millió embert jelent világszerte, míg Magyarországon két-, illetve egymillió embert. A WHO becslése szerint 2020-ra a depresszió lesz a munkaképesség-csökkenés második leggyakoribb oka. Ugyan a szorongásos zavarok gyakran együtt járnak a depresszióval, a szorongásos zavarok önmagukban is előfordulhatnak. Az Európai Unió felnőtt lakosságában a szorongásos zavarok a leggyakrabban előforduló mentális betegségek, egyéves prevalenciájuk 14\%, Magyarországon ez a szám még magasabb, $17 \%(11)$.

A depresszió és a szorongás kapcsolatáról a metabolikus szindrómával és az annak következtében kialakuló betegségekkel számos tanulmány született $(12,13,14$, $15,16)$. Felnőtt populáción végzett vizsgálatok szerint elhízás esetén (BMI >30) kb. 20-45\%-kal gyakrabban van jelen unipoláris depresszió, pánikbetegség, de leginkább bipoláris zavar (15). Gil és munkatársai szignifikáns összefüggést találtak a depressziós tünetek és a zsigeri elhízás között férfiak esetében, míg nőknél a depresszió és a hyperglykaemia között találtak kapcsolatot (16). Más kutatók fordítva közelítették meg a metabolikus szindróma és a depresszió kapcsolatát: a metabolikus szindróma unipoláris depresszióban 40$48 \%$-ban, míg bipoláris zavarnál 25 és $49 \%$ között van jelen (17).

Ali és munkatársai hasonló eredményre bukkantak: a cukorbetegek 17,6\%-ánál fordult elő depresszió, míg a kontrollcsoportban 9,8\%-nál (18). Egy hétéves utánkövetéses vizsgálatai szerint azok között, akiknél a vizsgálat kezdetén diagnosztizálták a metabolikus szindrómát, az utánkövetés során kb. 2,2-szer nagyobb eséllyel alakult ki depresszió a kontrollcsoporthoz képest (19), míg egy korábbi, nőkkel végzett, szintén hét évig tartó kutatás szerint, annak kezdetén jelenlévő depressziós tünetek fokozták az utánkövetés során kialakult metabolikus szindróma gyakoriságát, azonban fordítva, a metabolikus szindróma megléte nem növelte szignifikánsan a depresszió kialakulásának valószínüségét (20).

Meurs és munkatársai keresztmetszeti vizsgálatukban a depresszió és a szorongás együttes előfordulását tanulmányozták 90686 fős mintán, akiket 3 csoportra osztottak:

1. diagnosztizált cukorbetegek;

2. cukorbetegek, akik nem tudtak betegségükről;

3. nem cukorbetegek.

A depresszió előfordulási gyakorisága magasabb volt a cukorbetegek között, a diagnózis ismeretétől függetlenül (21).

Egy svéd kutatás a negatív pszichés események hatását elemezte magas éhgyomri vércukor és csökkent cukortolerancia, illetve 2-es típusú cukorbetegség létrejötte vonatkozásában. Az eredmények szerint az apátia, a depresszió, a szorongás és az álmatlanság szignifikánsan megnövelte az anyagcsere károsodásának kialakulását (22).

A metabolikus szindróma valamint a depresszió és a szorongás közötti kapcsolat tehát többszörösen alátámasztott, azonban az ok-okozati összefüggés nem tisztázott. Egyes kutatások kétirányú kapcsolatot feltételeznek, amit közös etiológiai háttérrel magyaráznak. A betegségek genetikai háttere közötti összefüggés vizsgálatát azonban nehezíti, hogy azok multifaktoriális kórképek. Több mint 37000 fős mintán végzett, egy- és kétpetéjü ikervizsgálatok során svéd kutatók fokozott genetikai kockázatot kerestek a 2-es típusú cukorbetegség és a depresszió egyidejü előfordulására, azonban nem találtak egyértelmú összefüggést (23). Ezzel szemben más kutatók kapcsolatot találtak az agy specifikus triptofán-hidroxiláz-2 (TPH2)-génje és a metabolikus szindróma kockázata között: a TPH2 polimorfizmusa a depressziós betegek egy olyan alcsoportjára jellemző, akik hajlamosabbak a metabolikus szindróma kialakulására (24).

A depresszió, a szorongás és a metabolikus szindróma esetében számolnunk kell viselkedéses rizikótényezőkkel is, mivel számos tanulmány igazolja, hogy a depressziós és szorongásos zavarok együtt járhatnak a mozgásszegény életmóddal, az egészségtelen táplálkozással, és a dohányzással $(25,26)$.

A depresszió tünetei között fontos a stresszrendszer aktiválódásának és zavarának szerepe is, hiszen a tartós stressz aktiválja a hypothalamus-hypophysismellékvese tengelyt és a szimpatikus idegrendszert, ami megemeli a kortizol, az adrenalin- és a noradrenalinszintet, ez pedig inzulinrezisztenciához, visceralis obesitashoz, metabolikus szindrómához és 2-es típusú cukorbetegség kialakulásához vezethet (27). Ezzel egy időben a szerotoninrendszer alulműködése fokozott étvággyal járhat együtt (28).

$A z$ anyagcsere felborulásához és az inzulinrezisztencia kialakulásához jelentősen hozzájárul a depresszió egyik leggyakoribb tünete és következménye, a cirkadi- 
án ritmus felbomlása is. Ennek hatására megváltozik a növekedési hormon, kortizol, prolaktin, egyes citokinek, TSH és a testhőmérséklet értékei. A megzavart alvás lecsökkenti a szervezet leptinszintjét, és megnöveli az éhséget közvetítő ghrelinszintet, tehát étvágyfokozó hatású (29).

Nem utolsó sorban a depresszió és szorongás kapcsán fontos megemlíteni az azok kezelésére használt antidepresszáns-hatású gyógyszereket is, amelyek bár javítják a beteg hangulatát, fájdalomcsökkentő hatásuk is van és növelhetik a betegek terápiás adherenciáját is, azonban a különböző mellékhatásokon különböző mellékhatásokon keresztül - testsúlynövekedés, hyper-, hypoglykaemiás hatás - ronthatják a szénhidrátháztartást is (27). Eker és munkatársai 624 fős mintán végzett vizsgálatából kiderült, hogy az antidepresszánsokkal való kezelés megkezdése után a metabolikus szindróma gyakran és egészen korán megjelent, az esetek többségében a kezelés első három hónapjában, illetve súlyosbodott azoknál a betegeknél, akiknél már a kezelés előtt jelen volt (30). Az első generációs antidepreszszívumok a tri- és tetraciklikus hangulatjavítók (TCA-k) hisztamingátló hatása étvágynövekedést okoz, amihez hozzáadódik a szedatív komponens is, csökkentve ezáltal a kalórialeadást és fokozva a súlygyarapodást. Tartós alkalmazás során kardiovaszkuláris rizikót is jelenthetnek: növelhetik a szívfrekvenciát, a vérnyomást (31). A második generációs antidepresszívumok egyik csoportja a szelektív szerotoninvisszavétel-gátlók (SSRI-k) általában nem befolyásolják a testsúlyt, kivétel a paroxetin, amely súlygyarapodást és a fluoxetin, ami pedig a kezelés elején testsúlycsökkenést, majd tartósan testsúlynövekedést eredményez (31). Beyazyüz és munkatársai 16 hetes vizsgálata is azt mutatta, hogy a generalizált szorongásos betegeknél a paroxetin jelentősen megnövelte a testsúlyt, a testtömegindexet, a derékkörfogatot, az éhgyomi vércukorszintet, a koleszterinszintet és a trigliceridszintet a kezelés során (32). Harmadik generációs antidepresszánsok közül a trazodon kis vagy közepes mértékű testsúlygyarapodást okozhat, de az étvágyat negatív irányban is befolyásolhatja. A szerotonin-noradrenalin-visszavétel-gátló közül a venlafaxin metabolikus hatása elenyésző, sőt falásrohamok (binge eating disorder) kezelésére is alkalmas, a duloxetin pedig emelheti a vércukorszintet, és enyhe súlygyarapodást okozhat (33).

A depresszió kezelésére használt antidepresszívumok tehát bizonyítottan hozzájárulhatnak a metabolikus szindróma kialakulásához.

\section{Egészségkontrollhit kapcsolata a metabolikus szindrónmával}

A kontrollhely (locus of control) fogalma Julian B Rotter, a szociális tanuláselmélet megalkotójának nevéhez füződik. Rotter szerint az emberek megkülönböztethe- tők a tekintetben, hogy a viselkedésük és az azt követő események-következmények között milyen erősségü ok-okozati kapcsolatot látnak (34). Wallston és munkatársai dolgozták ki az első kérdőívet az egészséggel kapcsolatos kontrollhit mérésére, amely egydimenziós volt és a két végponton külső és belső kontrollt különböztetett meg. Külső kontroll esetén a személyek úgy vélik, hogy az egészségük elsősorban a szerencsétől vagy más személyektől függ, míg a belső kontroll esetén úgy vélik, hogy ők maguk vannak döntően hatással a saját egészségükre (35).

Az egészséggel kapcsolatos kontrollhit befolyásolja az egyén egészséggel kapcsolatos viselkedését, és ezáltal meghatározza az egészségi állapotát (36). Fontos azonban megjegyeznünk, hogy ez a kapcsolat kétirányú: az egészségi állapot is befolyásolhatja a személy egészségkontrollhitét (például: egyszerre több betegségben szenvedők kontrollhite nagyobb mértékben külső orientációjú $(37,38)$. A vizsgálatok kimutatták továbbá a kontrollhit kapcsolatát az egészséggel kapcsolatos attitűdjeinkkel, érzelmeinkkel, megküzdési módjainkkal, észlelt énhatékonyságunkkal és viselkedési kontrollunkkal $(39,40)$.

$A z$ egészség megőrzése és javítása szempontjából fontos tényező az egészségkontrollhit, amely arra utal, hogy az egyén milyen összefüggést vél viselkedése és annak egészségét érintő következményei között. Ennek megfelelően a szakirodalom háromféle csoportot különböztet meg:

1. véletlen külső kontrollhittel rendelkezők: akik úgy vélik, hogy az egészségük döntően a szerencsétől és a sorstól függ;

2. társas külső kontrollhittel bírók: akik szerint egészségük más emberektől (például családtag, barát, egészségügyi személyek) függ;

3. belső kontrollhitűek: akik úgy vélik, hogy saját maguk gyakorolnak döntő hatást egészségükre $(34,35)$.

A belső kontrollhit pozitív egészségmagatartásokkal, pozitív érzelmekkel, míg a külső kontrollhit két csoportja egészségtelenebb viselkedésmódokkal (dohányzás, alkoholfogyasztás, egészségtelenebb étkezés, kevesebb testmozgás) áll összefüggésben (41). A külső kontrollt vizsgáló tanulmányokból az derült ki, hogy a külső kontroll a mások elismerése, másoknak való túlzott megfelelés révén szorongásos tünetekre hajlamosító tényezővé válhat, hiszen az ilyen attitűd közvetlenül és közvetve a megküzdési stratégiákon keresztül (a problémafókuszú stratégiákat gyengítve, az érzelemfókuszúkat pedig erősítve) is befolyásolja a szorongásos panaszok kialakulását (42)

Rafael, Konkoly Thege, Kovács és Balog Csongrád megyében 121 iszkémiás szívbetegségben szenvedő egyén egészségkontrollhitét vizsgálta életkor, nem, iskolai végzettség, betegségteher és szubjektív egészségi állapot tükrében. A következő eredményeket kapták: legmagasabb átlagérték a társas külsőkontroll-dimenziónál mutatkozott, a legalacsonyabb érték pedig a vé- 
letlen külsőkontroll-dimenziónál. Tehát a vizsgált személyek többsége úgy gondolja, egészsége másokon (orvosok, nővérek, család és barátok) múlik. A férfiak belső kontrollja és társas külső kontrollja szignifikánsan magasabb volt a nőkéhez képest, életkori tekintetében a 60 éves és annál idősebb személyek mutattak szignifikánsan magasabb értéket a belső kontroll terén (43). Ez némileg ellentmond egyéb kutatások eredményeinek, miszerint a belsőkontrollskála magasabb értékét a 35-64 évesek között találták, míg a 65-74 évesek a véletlen külső skálán jeleztek magasabb értéket. A társas külső skála értéke fokozatosan emelkedett 45 és 54 év között (39). Családi állapot alapján a házastársi/ élettársi kapcsolatban élők belső és a társas külsőkontroll-dimenziókban mutattak magasabb átlagértéket. Iskolai végzettség alapján nem mutatkoztak eltérések az egészségkontrollhit dimenziói terén. A nagy betegségterhet megélők szignifikánsan alacsonyabb pontszámot értek el a belsőkontroll-dimenzióban a kismértékü terhet megélőkhöz képest. A belsőkontroll-dimenzió gyenge pozitív együttjárást mutatott a rendszeres testmozgással, míg a társas külsőkontrollskála szintén gyenge pozitív kapcsolatot jelzett az orvosi segítségkéréssel (43). Egy átfogó tanulmányban 18 európai ország több mint 7000 egyetemi hallgatójánál vizsgálta az egészségkontroll és egészségmagatartás kapcsolatát. A belsőkontrollskálán magasabb pontszámot elérők többet sportoltak, rendszeresen reggeliztek, mindennap mostak fogat, a magas rosttartalmú, az alacsony sótartalmú, valamint a zsírszegény ételeket részesítették előnyben, míg a véletlen külső skála fordított összefüggést mutatott az egészséges magatartásmódokkal (dohányzás, alkoholfogyasztás, rendszeres reggelizés, gyümölcsfogyasztás, rostos és zsíros étkezés) (44).

Az egészségkontrollhit és a metabolikus szindróma közötti közvetlen kapcsolat kevésbé kutatott, azonban bizonyított, hogy a kontrollhit meghatározza az egyén egészséggel/betegséggel kapcsolatos attitüdjét, viselkedését. Az életmód pedig nagyban hozzájárul mind a metabolikus szindróma, mind a kardiovaszkuláris betegségek, 2-es típusú diabétesz kialakulásához, tehát a kezelés során az orvosnak mindenképpen érdemes figyelembe venni a pszichoszociális tényezőket, többek között a depressziót és szorongást, illetve az egészségkontrollhitet is.

\section{Megbeszélés}

Bár a depresszió és szorongás kapcsolatában a metabolikus szindrómával az ok-okozati összefüggés nem tisztázott, a metabolikus szindróma elöszobájaként tekintett elhízás és az annak következményeként jelentkező cukorbetegség esetén is gyakrabban van jelen unipoláris depresszió, pánikbetegség, vagy bipoláris zavar - a cukorbetegség diagnózisának ismeretétől függetlenül $(15,21)$. Továbbá, a metabolikus szindróma unipoláris depresszióban 40-48\%-ban, míg bipoláris zavarnál 25 és $49 \%$ között van jelen (17).

Az egészségkontrollhitet tekintve a belsőkontrollhit pozitív érzelmekkel és pozitiv egészségmagatartással járhat együtt: ezek az egyének többet sportolnak, rendszeresen reggeliznek, mindennap mosnak fogat, a magas rosttartalmú, az alacsony sótartalmú, valamint a zsírszegény ételeket részesítik előnyben. Ezzel szemben a külső kontroll két dimenziója egészségtelenebb viselkedésmódokkal (dohányzás, alkoholfogyasztás, egészségtelenebb étkezés, kevesebb testmozgás) áll összefüggésben (41).

A szakemberek a metabolikus szindróma terápiájának első lépéseként életmódbeli változtatást javasolnak, amely magában foglalja a megfelelő fizikai aktivitást, egészséges táplálkozást, testtömegcsökkentést, a dohányzás és alkoholfogyasztás mellőzését (45). A fogyással elért eredmények megtartása azonban igen nehéz, 5-10 éves utánkövetés során a túlsúlyos személyeknek csupán $6-20 \%$-a tudta az 5-10\%-os testsúlycsökkenését megőrizni (46).

Ezen folyamathoz eszközként segítségül hívható a motivációs interjú, amivel a beteg belső motivációit próbálják meg felerősíteni, a saját céljaival és elérésükben akadályozó magatartásformával szembesíteni, ezzel elindítva a változást. Öt alapelvet szükséges figyelembe vennie az interjúkészítőnek:

- empatikus viselkedés,

- a páciens segítése az ellentmondás felismerésében,

- vitatkozás kerülése, mert az gyakran kontraproduktív hatást érhet el,

- ellenállás esetén stratégiaváltás,

- az önhatékonyság érzésének támogatása (47).

Az életmódváltással járó mindennapos nehézségek, a gyógyszeres kezelés esetleges mellékhatásai, valamint a félelem az inzulinkezeléstöl azonban növelhetik a páciens szorongását és akár depressziós tüneteket is elöidézhetnek, amelyek tovább ronthatják az anyagcsere állapotát, hozzájárulhatnak egyéb metabolikus és vaszkuláris szövődmények kialakulásához $(31,48)$. Ezért a metabolikus szindrómával diagnosztizált egyének kezelése során az egészséges életmód és testmozgás mellett fontos a megfelelő szocio-pszichés környezet megléte is. A szakemberek álláspontja szerint a metabolikus szindrómában szenvedő egyén csak önmagát tudja "meggyógyítani”, az orvos feladata segíteni őt a sikeres self-management kialakításában, amelynek feltételei a személyes képességek (önbizalom, problémamegoldó készség), jó orvos-beteg kommunikáció, elegendő ismeret, motiváció, szociális adottságok (szükebb családi és tágabb társadalmi környezet) (49).

A társuló pszichés zavarok, mint a szorongás, depreszszió azonban rontják az önkezelés minőségét, ezért fontos korai felismerésük és kezelésük. Mivel a depresszió kezelésére használt antidepresszívumok közül több is 
testsúlygyarapodást okozhat (elsősorban a triciklikus antidepresszívumok), ezáltal bizonyítottan hozzájárulhatnak a metabolikus szindróma kialakulásához, ezért a komorbid depresszió kezelése során a mellékhatások tekintetében fokozott figyelemmel kell alkalmazni a farmakoterápiát, és lehetőség szerint pszichoterápiával például kognitív viselkedésterápiával, kombinálni a kezelést $(31,49,50)$. A kognitív viselkedésterápia célzott megoldást nyújthat a betegséggel kapcsolatos aktuális problémákra, a diszfunkcionális gondolkodás és viselkedés megváltoztatásával. Ezzel a módszerrel a maladaptív viselkedésformák kedvező irányú befolyásolása és a hiányzó viselkedések kialakítása a cél (50).

$A z$ életmódváltás során a beteg egészségkontrollhitének is jelentős szerepe van. A külső kontroll két csoportja egészségtelenebb viselkedésmódokkal (dohányzás, alkoholfogyasztás, egészségtelenebb étkezés, kevesebb testmozgás) áll összefüggésben (41). A külső kontrollos egyéneknek nagyobb terhet, erőfeszítést jelenthet az életmódváltás, ezért esetükben kiemelten fontos a megfelelő edukáció, orvos-beteg kommunikáció és kapcsolat, illetve az utánkövetés. A külső kontrollos egyének azért is veszélyeztettek, mert az ilyen attitüd közvetlenül és közvetve a megküzdési stratégiákon keresztül (a problémafókuszú stratégiákat gyengítve, az érzelemfókuszúkat pedig erősítve) is befolyásolja a szorongásos panaszok kialakulását (42). Érzelemközpontú megküzdési stratégia lehet az evés, ami a metabolikus szindrómával diagnosztizált egyének életében központi szerepet tölt be, az étkezés fölötti kontroll gyenge, sérülékeny. A kudarcaikat, csalódásaikat gyakran evéssel kompenzálják, majd a kontroll elveszítése miatt büntudatot, feszültséget éreznek, ami depresszióhoz vezethet és egy önrontó körbe taszítja őket. Ha ebben az időszakban a kezelőorvostól szemrehányást kapnak, az tovább növeli a feszültséget, rontja az önértékelést, fokozza a szorongást, depressziót (49).

Sal és munkatársai egy a metabolikus szindróma, illetve a 2-es típusú cukorbetegség kezelésére alkalmas viselkedésterápiás testsúlycsökkentő programról számolnak be, amelynek alapja Prochaska és DiClemente elméleti modellje. A modell legelső szakasza a töprengés előtti időszak, amikor az egyén nincs tudatában a problémának, vagy nincs szándékában változtatni a viselkedésén. A második, tépelődés szakaszában felismeri és hajlandó közelebbről is megvizsgálni a problémát, mérlegeli a változás hatásait, de kevés eséllyel tesz lépéseket a változás érdekében. Következő lépés az előkészület, amikor igényli a segítséget, de gyakran nem tudja, még mit kellene tennie. A legtöbb páciens ebben a szakaszban érkezik a szakemberhez. Az előkészület során a legfontosabb a megfelelő információk átadása a betegségről, a páciens motiválása a változásra. Ez a szakasz a legfontosabb a beteg elköteleződése és későbbi eredmény szempontjából. Ez főleg azoknál az egyéneknél jelent nagy kihívást, akiknél a túlsúly még nem okoz testi tüneteket. Ök többnyire tisztában vannak az egészséges életmód feltételeivel, ezért elsősorban az ellentmondásos információk tisztázására, alapismeretek rögzítésére, gyakorlati hasznosságra kell helyezni a hangsúlyt. A következő lépés a cselekvés szakasza, amikor a beteg aktívan részt vesz az életmódváltásban, kompetensnek és felelősnek érzi magát a változásokért. Ennek a folyamatnak fokozatosan kell megtörténnie és külön figyelmet kell fordítani a különleges helyzetekre, nehézségekre, pszichés tényezőkre. A szakemberrel való találkozások ekkor elkezdenek ritkulni, ami elősegíti a beteg kontrolljának és kompetenciaérzetének növelését. Ekkor kezdődik az utolsó, fenntartás szakasza. A legfontosabb cél a változások rögzítése, motiváció fenntartása és a beteg belső kontrolljának kialakítása (49).

A metabolikus szindróma tehát elsődlegesen életmódváltással kezelhető kórkép. Ahogy azonban a modell is mutatja, a tartós testsúlycsökkenés és életmódváltás egy hosszú, komplex folyamatot igényel, amelyben a pszichoszociális tényezők kiemelkedő szerepet játszanak, ezért orvoslásában kiemelten fontos - az orvostudományban a biomedikus modell helyett egyre inkább elterjedt - biopszichoszociális modellre épülő komplex betegvizsgálat. A diagnózis felállítását és a beteg ismereteinek bővítését követően a hatékony terápia feltétele a beteg belső kontrolljának, kompetencia- és felelősségérzetének növelése és a megfelelő támogatás az orvos és környezete részéről.

\section{Támogatás}

A kézirat az Európai Unió támogatásával, az Európai Szociális Alap társfinanszírozásával jött létre az EFOP-3.6.116-2016-00008 projekt (Szegedi Tudományegyetem, „Testi, lelki, és szociális egészségmegőrzés és betegségmegelőzés multidimenzionális vizsgálata, és megvalósítható egészségvédő programok kidolgozása") keretében.

\section{Nyilatkozat}

A szerzők kijelentik, hogy az összefoglaló közlemény megírásával kapcsolatban nem áll fenn velük szemben pénzügyi vagy egyéb lényeges összeütközés, összeférhetetlenségi ok, amely befolyásolhatja a közleményben bemutatott eredményeket, az abból levont következtetéseket vagy azok értelmezését.

\section{Irodalom}

1. Paré G, Jaana M, Sicotte C. Systematic review of home telemonitoring for chronic diseases: the evidence base. JAMIA 2007; 14(3): 269-77. 2. Carrera-Bastos $P$, Fontes, O'Keefeet, et al. The western diet and lifestyle and diseases of civilization. Res Rep Clin Cardiol 2011; 2: 15-35. https://doi.org/doi.org/102147/RRCC.S16919

3. Kőműves $\mathrm{S}$. Az engeli biopszichoszociális modell Tudományelméleti alappozícióból levezetett orvosi szereptartalom. Metszetek 2017; 6(2). https://doi.org/10.18392/metsz/2017/3/10

4. Al-Qawasmeh RH, Tayyem,RF. Dietary and Lifestyle Risk Factors and Metabolic Syndrome: Literature Review. Curr Res Nutrit Food Sci 2018; 6(3): 594-608. https://doi.org/10.12944/CRNFS.I.6.3.03 5. Alberti KG, Eckel RH, Grundy et al. Harmonizing the metabolic syndrome: a joint interim statement of the International Diabetes Federation Task Force on Epidemiology and Prevention; National Heart Lung, and Blood Institute; American Heart Association; World Heart 
Federation; International Atherosclerosis Society; International Association for the Study of Obesity. Circulation 2009; 120: 1640-1645. https://doi.org/10.1161/CIRCULATIONAHA.109.192644

6. Jermendy Gy, Barkai L, Halmos T, et al. A metabolikus szindróma klinikai jelentősége 2011-ben. A Magyar Diabetes Társaság Metabolikus Munkacsoportjának állásfoglalása. Orvosi Hetilap 2011; 152(36): 1450-1458. https://doi.org/10.1556/OH.2011.29203

7. Szollár L, Pados Gy, Balogh S, et al. Összefoglalás az V. Magyar Kardiovaszkuláris Konferencia ajánlásairól. Metabolizmus 2010; 10(Suppl A): A2-A4

8. Nádas J. A metabolikus szindróma néhány klinikai vonatkozása a hazai lakosság körében végzett vizsgálatok alapján. Doktori disszertáció Budapest: SE Klin Orvostud Doktori Iskola; 2009.

9. Kékes E, Barna I, Daiki T, et al. A metabolikus szindróma „Magyarország Átfogó Egészségvédelmi Szüûrőprogramja 2010-2020, 2010 2012. évi tevékenységének tükrében. Hypert Nephrol 2013; 17(2): 75-81. 10. Simmons RK, Alberti KGMM, Gale, EAM, et al. The metabolic syndrome: useful concept or clinical tool? Report of a WHO Expert Consultation. Diabetologia 2010; 53: 600-605.

https://doi.org/10.1007/s00125-009-1620-4

11. Németh A, Szőnyi $G$, Füredi J et al. A pszichiátria rövidített kézikönyve. Budapest: Medicina; 2007.

12. Limon VM, Lee M, Gonzalez B, et al. The impact of metabolic syndrome on mental health-related quality of life and depressive symptoms. Qual Life Res 2020; 29: 2063-2072.

https://doi.org/10.1007/s11136-020-02479-5 T

13. Sharafi SE, Garmaroudi G, Ghafouri M, et al. Prevalence of anxi ety and depression in patients with overweight and obesity. Obes Med 2020; 100169. https://doi.org/10.1016/j.obmed.2019.100169

14. Dregan A, Rayner L, Davis KAS. Associations Between Depres sion, Arterial Stiffness, and Metabolic Syndrome Among Adults in the UK Biobank Population Study A Mediation Analysis. AMA Psychiatry 2020; 77(6): 598-606. https://doi.org/10.1001/jamapsychiatry.2019.4712 15. Simon GF, Von Korff, M, Saunders K, et al. Association between obestiy and psychiatric disorders in the US adult population. Arch Gen Psychiatry 2006; 63: 824-830. doi:10.1001/archpsyc.63.7.824

16. Gil K, Radziłłowicz P, Zdrojewski T. Relationship Between the Prevalence of Depressive Symptoms and Metabolic Syndrome. Results of the SOPKARD Project. Kardiol Pol 2006; 64(5): 464-469. PMID: 16752328 17. Kim B, Kim, SJ, Son JI, et al. Weight change in the acute treatment of bipolar I disorder: a naturalistic observational study of psychiatric inpatients. J Affect Disorders 2008; 105(1-3): 45-52.

https://doi.org/10.1016/j.jad.2007.04.006

18. Ali S, Stone MA, Peters JL, et al. The prevalence of co-morbid depression in adults with type 2 diabetes: a systematic review and meta-analysis. Diab Med 2006; 23(11): 1165-1173

https://doi.org/10.1111/j.1464-5491.2006.01943.x.

19. Koponen $\mathrm{H}$, Jokelainen J, KeinänenKiukaanniemi $\mathrm{S}$, et al. Metabolic Syndrome Predisposes to Depressive Symptoms: A PopulationBased 7-Year Follow-Up Study. J Clin Psychiatry 2008; 69(2): 178-182. https://doi.org/10.4088/jcp.v69n0202

20. Räikkönen K, Matthews KA, Kuller LH. The relationship between psychological risk attributes and the metabolic syndrome in healthy women: antecedent or consequence? Metabolism, 2002; 51(12): 1573-1577. https://doi.org/10.1053/meta.2002.36301.

21. Meurs M, Roest AM, Wolffenbuttel BHR, et al. Association of depressive and anxiety disorders with diagnosed versus undiagnosed diabetes. Psychosom Med 2016; 78(2): 233-412.

https://doi.org/10.1097/PSY.0000000000000255

22. Eriksson AK, Ekbom A, Granath F, et al. Psychological Distress and Risk of PreDiabetes and Type 2 Diabetes in a Prospective Study of Swedish Middle-Aged Men and Women. Diab Med 2008; 25(7): 834-842 https://doi.org/10.1111/j.1464-5491.2008.02463x

23. Mezuk B, Eaton WW, Albrecht $S$ et al. Depression and type 2 diabetes over the lifespan: a meta-analysis. Diab Care 2008; 31(12): 2383-2390. https://doi.org/10.2337/dc08-0985

24. Kloiber S, Kohli MA, Brueckl T, et al. Variations in tryptophan hydroxylase 2 linked to decreased serotonergic activity is associated with elevated risk for metabolic syndrome in depression. Mol Psychiatry 2010; 15(7): 736-747. https://doi.org/10.1038/mp.2008.142.

25. Bonnet F, Irving K, Terra JL, et al. Anxiety and depression are as sociated with unhealthy lifestyle in patients at risk of cardiovascular disease. Atherosclerosis 2005; 178(2): 339-344

https://doi.org/10.1016/j.atherosclerosis.2004.08.035

26. Mouchacca, J, Abbott, GR, Ball K. Associations between psychological stress, eating, physical activity, sedentary behaviours and body weight among women: a longitudinal study. BMC public health, 2013; 13(1): 828 27. Hargittay Cs, Márkus B, Vörös K, et al. A diabetes és a depresszió együttes előfordulása, lehetséges kétirányú kapcsolata és szűrésük jelentősége. Orvosi Hetilap 2019; 160(21): 807-814.

https://doi.org/10.1556/650.2019.31400

28. Rihmer Z, Purebl Gy, Faludi G, et al. Az elhízás és a depresszió kapcsolata. Neuropsychopharmac Hun 2008; 10(4): 183-189.

29. Turek FW. From circadian rhythms to clock genes in depression. International Clin Psychopharmacol 2007; 22(Suppl 2): S1-8. https://doi.org/10.1097/01.yic.0000277956.93777.6a

30. Eker OÖ, Özsoy S, Baki E, et al. Metabolic Effects of Antidepressant Treatment. Archives of Neuropsychiatry 2017; 54(1): 49-56. https://doi.org/10.5152/npa.2016.12373

31. Kolcsár M, Gáll Zs, Bába LI, et al. Antidepresszánsok és a metabolikus szindróma. Orvostud Ért 2016; 91(2): 89-98.

https://doi.org/10.2478/orvtudert-2018-0009

32. Beyazyüz M, Albayrak Y, Eğilmez $O B$, et al. Relationship between SSRIs and Metabolic Syndrome Abnormalities in Patients with Generalized Anxiety Disorder: A Prospective Study. Psychiat Invest 2013 10(2): 148-154. https://doi.org/10.4306/pi.2013.10.2.148

33. Olguner EO, Ozsoy S, Eker B. et al. Metabolic Effects of Antidepressant Treatment. Arch Neuropsychiatr, 2017; 54(1): 49-56. https://doi.org/10.12944/CRNFSJ.6.3.03

34. Rotter JB. Generalized Expectancies for Internal Versus External Control of Reinforcement. Psychol Monogr 1966; 80(609): 1-28. https://doi.org/10.37/h0092976

35. Wallston BS, Wallston KA, Kaplan GD et al. Development and Validation of the Health Locus of Control (HLC) Scale. J Consult Clinic Psychol 1976; 44(4): 580-585

https://doi.org/10.1037/0022-006X.44.4.580

36. Wallston KA, Stein MJ, Smith CA. Form C of the MHLC scales: A condition-specific measure of locus of control. J Pers Assess 1994 63(3): 534-553. https://doi.org/10.1207/s15327752jpa6303_10

37. van der Linden $M$, van den Akker M, Buntinx F. The relation between health locus of control and multimorbidity: a case-control study Pers Indiv Differ 2001; 30: 1189-1197.

https://doi.org/10.1016/S0191-8869(00)00102-1

38. Henninger DE, Whitson $\mathrm{HE}$, Cohen $\mathrm{HJ}$, et al. Higher comorbidity burden is associated with external locus of control. J Am Geriatr Soc 2012; 60(4): 751-755. https://doi.org/10.1111/j.1532-5415.2012.03904.x

39. Jacobs-Lawson J, Waddell EL, Webb AK. Predictors of health locus of control in older adults. Curr Psychol 2011; 30(2): 173-183.

https://doi.org/10.1007/s12144-011-9108-z

40. Schafer T, Riehle A, Wichmann HE, et al. Alternative medicine and allergies. Life satisfaction, health locus of control and quality of life. J. Psychosom. Res 2003; 55: 543-546.

https://doi.org/10.1016/s0022-3999(03)00015-1

41. Wardle J, Steptoe A. Socioeconomic differences in attitude and beliefs about healthy lifestyles. J. Epidemiol Community Health 2003; 57(6): 440-443. https://doi.org/10.1136/jech.57.6.440

42. Mészáros V, Ajtay Gy, Fodor K, et al. Az életeseményektöl a depressziós és szorongásos panaszokig: a diszfunkcionális attitüdök és a megküzdés szerepe a patogenezis folyamatában. Ideggyógy Szemle 2014; 67(11-12): 397-408. http://real.mtak.hu/id/eprint/25314

43. Rafael B, Konkoly Thege B, Kovács $P$ et al. Szorongás, depresszió, egészségkontrollhit és az egészség-magatartással való kapcsolatuk ischaemiás szívbetegek körében. Orvosi Hetilap, 2015; 156(20): 813-822. 44. SteptoeA, Wardle J. Locus of control and health behaviour revisited: A multivariate analysis of young adults from 18 countries. British J Psychiatry 2001; 92(4): 659-672. https://doi.org/10.1348/000712601162400 45. Paragh Gy, Balogh Z, Fülöp P. A metabolikus szindróma kezelése. Metabolizmus 2008; 6(3): 163-168.

46. Tabák GyÁ. A 2-es típusú cukorbetegség és a metabolikus szindróma nem gyógyszeres kezelése. LAM-Tudomány 2006; 16(6): 543-550. 47. Barnes RD, Barber JA Preliminary examination of metabolic syndrome response to motivational interviewing for weight loss as compared to an attentional control and usual care in primary care for individuals with and without binge-eating disorder. Eating Behav 2017; 26 : 108-113. https://doi.org/10.1016/j.eatbeh.2017.02.007

48. Halmos T, Suba I. A depresszió kapcsolata a 2-es típusú diabétesszel és a metabolikus szindrómával. Magyar Tud 2009; 170(9): 1118-1127. 49. Sal I, Papp I, Perczel FD. Magatartás-orvoslási lehetőségek a cukorbetegség és az elhízás kezelésében. Orvosi Hetilap, 2001; 153: 410-417. https://doi.org/10.1556/OH.2012.29290

50. Zhang Y, Mei S, Yang R, et al. Effects of lifestyle intervention using patient-centered cognitive behavioral therapy among patients with cardio-metabolic syndrome: a randomized, controlled trial. BMC Cardiovasc Disorders 2016; 16(1): 227.

https://doi.org/10.1186/s12872-016-0398-9 